\title{
Review Article \\ Cell Proliferation in Cutaneous Malignant Melanoma: Relationship with Neoplastic Progression
}

\author{
G. E. Piérard \\ Department of Dermatopathology, University Hospital of Liège, 4000 Liège, Belgium \\ Correspondence should be addressed to G. E. Piérard, gerald.pierard@ulg.ac.be \\ Received 4 November 2011; Accepted 30 November 2011 \\ Academic Editors: S.-C. Chao and C. Johansen
}

Copyright () 2012 G. E. Piérard. This is an open access article distributed under the Creative Commons Attribution License, which permits unrestricted use, distribution, and reproduction in any medium, provided the original work is properly cited.

The establishment of the diagnosis of cutaneous malignant melanoma (CMM) always calls for histopathological confirmation. Further to the recognition of the CMM aspects, immunohistochemistry is helpful, in particular, in determining the size of the replicative compartment and the activity in each of the cell cycle phases $\left(G_{1}, S, G_{2}, M\right)$. The involvement of cancer stem cells and transient amplifier cells in CMM genesis is beyond doubt. The proliferation activity is indicative of the neoplastic progression and is often related to the clinical growth rate of the neoplasm. It allows to distinguish high-risk CMM commonly showing a high growth rate, from those CMMs of lower malignancy associated with a more limited growth rate. The recruitment and progression of CMM cells in the cell cycle of proliferation depend on mitogen-activated protein kinase (MAPK) pathway and result from a loss of control normally involving a series of key regulatory cyclins. In addition, the apoptotic pathways potentially counteracting any excess in proliferative activity are out of the dependency of specific regulatory molecular mechanisms. Key molecular components involved in the deregulation of the growth fraction, the cell cycle phases of proliferation, and apoptosis are presently described in CMM.

\section{Introduction}

For years, the incidence of human cutaneous malignant melanoma (CMM) is steadily on the rise [1]. CMM represents the leading cause of skin cancer death in the Caucasian populations from Westernized societies [2, 3]. Survival is dramatically decreased when distant metastases develop. Mortality rates vary by country, gender, and ethnic origin.

For decades, physicians searched for predictive indicators of the CMM metastatic risk. The regular classification and staging of sporadic CMM rely on the combination of gross clinical and microscopic aspects $[4,5]$. However, in some instances, the distinction of CMM from other atypical melanocytic neoplasms and the CMM staging prove to be difficult or uncertain [6]. The refinement of diagnostic assessments benefits from complementary immunohistochemical investigations [7-12]. Recent progress in the field of molecular biology brings further information resolving a series of translational quandaries [13-16]. In particular, it appears that transient amplifier neoplastic melanocytes, as well as melanocytic stem cells, participate in the CMM initiation and progression [15, 17-24].

Basically, most CMMs begin with the so-called radial growth phase corresponding to a slow-growing in situ and microinvasive phase. This condition is characterized by a high cure rate. Despite a trend toward earlier clinical recognition of CMM, by the time of diagnosis, most of the CMMs have already progressed to the next vertical growth phase typical for tumorigenic CMM and characterized by a faster growth rate [24]. In these neoplasms, cure becomes uncertain, and the prognosis depends on certain attributes of both the neoplasm and the host (stroma, immunity, etc.).

In general, the CMM clinical progression appears in part correlated with the enlargement of its germinative compartment $[23,24]$. The proportion of CMM cells engaged in the cell cycle of proliferation is increasing as well. However, some cases of smouldering CMM, CMM dormancy, and CMM regression exhibit peculiar aspects of tumor progression and cell proliferation [25-27]. 


\section{Smouldering CMM}

A variety of interrelations between CMM cells and the host are under the control of a vast array of factors. These interactions are not static, but result from a fluctuating imbalance between the neoplasm and the host, both being engaged in a process of natural selection. The variable combination over time of different cell processes involving CMM and its microenvironment possibly leads to a condition coined smouldering CMM [27].

The smouldering CMM concept was raised following a seminal study on CMM performed over more than 20 years [25]. The observational study scrutinized how the CMM metastases possibly varied in their evolution in each individual. The smouldering CMM phenomenon was defined as metastases unexpectedly appearing and disappearing on the same body region over months and years. In their wax and wane progression the metastases usually reached at the most the size of a pea or a bean [25]. Such condition was likely associated with contrasted active cell proliferation and apoptosis/necrosis.

The smouldering CMM phenomenon contrasts with the more common surge appearance of metastatic crops. This latter condition was particularly reported following excision of some primary CMM at a time when the metastatic disease remained silent and undisclosed. In short, smouldering CMM highlights the fact that CMM progression is not a fixed process and an ineluctable feature. Indeed, the net growth directionality of CMM metastasis proceeds through a combination between growth and regression. This evolution is influenced by (a) the possible prevalence of apoptosis over proliferation, (b) the versatile antitumoral immunity, and (c) the failure of stromal/vascular receptivity. Of note, inflammation in a variety of neoplasms boosts (a) the proliferation and survival of malignant cells, (b) angiogenesis, (c) metastasis release, and (d) subversion of adaptive immunity. In addition, inflammation potentially alters the response of the neoplasm to hormones and various chemotherapeutic agents [28]. Such a multifaceted process possibly leads to a programmed pathway of apoptosis and necrosis.

\section{CMM Dormancy}

Globally near 40\% of CMM patients develop clinical metastases 5 years or so after initial treatment. However, the disease-free interval before appearance of metastases possibly elapses 10 to 25 years or over. Any unusually long latency period between the primary CMM treatment and metastatic occurrence is commonly thought to result from clinical CMM dormancy [27]. It is associated with a protracted progression-free survival. The relationship between the CMM clinical dormancy and the CMM cell dormancy is complex and probably multifactorial. The neoplastic quiescence process is typically unstable and possibly leads to CMM relapse [29]. Any delay in CMM metastases suggests the implication of some host defence mechanism, and/or a peculiar nature of non- or slow-proliferating CMM cells possibly involving CMM stem cells [27].
Neoplastic dormancy and autophagy are partly correlated. Autophagy is a homeostatic and catabolic process involving cytoplasmic organelles and proteins. The process enables particle sequestration and their lysosomal degradation. Overall, autophagy is a mechanism of stress tolerance maintaining cell viability and possibly leading to any aspect of tumoral dormancy, progression, and therapeutic resistance [30]. Such a process is important for the maintenance of genomic stability and cell survival.

A dramatic example of CMM dormancy deals with metastases developed from transplant organs in drug-immunocompromised recipients [31,32]. Silent micrometastases present in the organ donor subject develop in an uncontrolled brisky way when the invaded organ is transplanted in the immunocompromised patient.

\section{Growth Fraction and Cell Kinetics in CMM}

Most cancers including CMM are composed of a number of different cell subpopulations expressing distinct cell kinetics, as well as atypical ploidies, different drug and radiation sensitivities, and variable metastatic potential. Whatever the source of cell heterogeneity, such cell diversity is present at different sites within each single neoplasm, at different metastatic locations in a given individual, and among patients exhibiting seemingly similar CMM types and stages.

The cell cycle of proliferation encompasses a sequential series of biochemical events leading to DNA replication and cell division [24]. The time elapsed between two successive cell divisions in a sustained dividing process corresponds to the cell cycle time $\left(T_{c}\right)$. After mitosis completion, the cell enters the $G_{1}$-phase. At a specific restriction point in early $\mathrm{G}_{1}$-phase, the cell sets in motion a specific biochemical step allowing progression through an ordered sequence of other biochemical steps leading to DNA replication during the Sphase. Alternatively, the cell enters into the nondividing quiescent $\mathrm{G}_{0}$-stage, thereby reducing the growth fraction (GF) of replicating cells. Once DNA duplication is completed, the cell enters the $\mathrm{G}_{2}$-phase that ends the process required for cell division. At mitosis the cell divides into two daughter cells which possibly reenter the $\mathrm{G}_{1}$-phase for reinitiating another cell cycle.

GF of any tissue or any neoplasm corresponds to the proportion of the cell population actually engaged in the cell cycle of proliferation. Clearly, GF is reduced by any segment of the cell population in the resting $\mathrm{G}_{0}$-stage. In addition, cell loss from the dividing and nondividing compartments occurs through cell apoptosis and necrosis as well as through metastatic cell escape. Therefore, the rate of cancer growth depends on three factors, namely, the average $T_{c}$, the GF, and the cell loss.

The time to proceed through the S-, $\mathrm{G}_{2}$ - and M-phases of the cell cycle remains fairly constant in any given tissue. By contrast, the extent in the $\mathrm{G}_{1}$-phase is more variable, in part due to the different restriction points controlling the progress through the cell cycle or the derivation to the $\mathrm{G}_{0^{-}}$ phase. The variability in the length of $\mathrm{G}_{1}$-phase makes $T_{c}$ frequently differ from cell to cell. Neoplastic cells generally exhibit a longer $T_{c}$ than the corresponding normal cells. This 
characteristic is in part explained by the presence of CMM stem cells exhibiting a lengthy $T_{c}$ [23]. The mechanisms ruling the proliferative activity $(P)$ in a given tissue are linked to both GF and the speed rate of the cell cycle with $P=$ $G F * T_{c}^{-1}$. Thus, more of the GF and $T_{c}$ singly defines the actual $P$ of a neoplasm. As a rule, $T_{c}$ is not accessible clinically and thus, $P$ of CMM remains not measurable.

\section{Immunohistochemistry and CMM Growth Fraction}

Both tumoral cell renewal and GF are important aspects determining in part the CMM malignancy potential. Regular counting of mitotic figures is a time-honored method used for assessing cell proliferation, but its sensitivity and reliability remain quite low because their numbers are usually low. To fine-tune such evaluation, any immunohistochemical method exploring one single specific facet of cell renewal requires the restricted expression or a prominent cellcycle-induced increase of a given target antigen in cycling cells. A number of antibodies to cell-cycle-related proteins fulfill such requirements. The target antigens belong to two distinct categories. One group comprises specific molecular compounds such as those involved in DNA synthesis during the S-phase. The second group encompasses cell-cycleassociated proteins, the most typical being represented by some histones and the MIB/Ki-67 nuclear antigen.

The proliferation marker MIB1/Ki-67 is produced and expressed during all active steps of the cell cycle of proliferation $\left(\mathrm{G}_{1^{-}}, \mathrm{S}-, \mathrm{G}_{2^{-}}\right.$, and M-phases), but its production is arrested in the $\mathrm{G}_{0}$-stage. The MIB1/Ki-67 monoclonal antibody provides a convenient means for evaluating the GF of CMM. The GF assessed by the Ki-67 index represents the ratio of cycling cells to the overall cycling and noncycling cells. Of note, cells that have run a part of the cell cycle before being rerouted at a restriction point to the $\mathrm{G}_{0}$ phase will retain the MIB/Ki-67 immunolabeling despite the fact they are no more part of the GF $[23,24]$. In several malignancies, in particular CMM, the Ki-67 index is indicative of the neoplastic progression, and it appears as an important prognostic indicator [5, 7, 10-12, 23, 24, 33-39].

Globally, the findings about the GF of CMM support the clinical concept distinguishing CMM of high and low growth rates, each bearing a different prognosis [40-42]. Cancer registries suggested the existence of three unrelated CMM types recognized as (a) thick CMM, with stable incidence over the past decades, (b) thin CMM mainly located on the trunk, and showing a dramatic increase in incidence over the past years, and (c) CMM mainly located on the head and neck region showing a moderate trend in incidence increase over time $[43,44]$. There is ample evidence that the GF extent in CMM is indicative of the neoplastic progression [13, 3337, 45-49]. Ki-67 immunolabeling is positive in less than $5 \%$ of nevocytes in most melanocytic nevi, but it commonly raises up to $15 \%$ or so in benign atypical melanocytomas and it reaches $15-30 \%$ or more in CMM $[5,7,10-12,33-37,47]$.

Any MIB1/Ki-67 index in CMM does not predict the number of cells completing mitosis. Indeed, all cycling cells including those arrested at a restriction point in the $\mathrm{G}_{1}$ phase are labeled. Hence, any fast-growing CMM is likely associated with a high MIB/Ki-67 index but a high MIB/Ki67 index does not always imply a fast growing neoplasm.

A stochastic relationship apparently prevails between CMM GF and tumor vascularity $[38,46]$. Nevertheless, clinically growth-stunted CMM appeared to be generally associated with a restricted blood vascularization [47]. Thus, it was inferred that the extent in blood microvasculature and the GF size of CMM were mostly correlated when angiogenesis was restricted [47]. Of note, the CMM GF appears to be influenced by the intra- and peri-CMM infiltration by Factor XIIIa-positive dendrocytes [34, 50, 51]. There is circumstantial evidence linking the density of Factor XIIIa-positive dendrocytes and a low proliferative rate in CMM cells [34]. The biologic and molecular mechanisms supporting these findings remain unsettled.

In short, two main clinical applications of the melanocyte kinetics emerge, namely, (a) deciphering the distinction between benign melanocytic neoplasms and CMM and (b) establishing or refining a clinical prognosis for CMM progression [8, 23, 24, 34-37].

\section{CMM Phase Indexes}

Two phase indexes are of particular interest in CMM. They correspond to the S- and M-phases. Any phase index is defined as the proportion of cells engaged in that given phase of the cell cycle. Some of these cells are specifically recognized by morphology (mitosis), and others are possibly labeled (Sphase). There is no fixed correlation between the GF and any specific phase index. Indeed, the proportion of cells in a given cell cycle phase depends on both GF and the relative duration of that cycle phase (phase duration $/ T_{c}$ ). Different CMM cell populations, particularly their metastases, show different phase indexes due to (a) differences in their GF while the ratios between their respective phase durations to $T_{c}$ are similar, (b) differences in the ratio of phase duration to $T_{c}$ while their respective GF remains similar, (c) differences in the total phase duration while their respective replicative activity is similar, or (d) differences in their replicative activities while their phase durations are similar [23, 24]. Among distinct CMM exhibiting different phase indexes, the neoplasm exhibiting the higher value in a given phase index is not necessarily the most proliferative one.

A landmark study was performed 25 years ago using incorporations of tritiated thymidine $\left({ }^{3} \mathrm{H}-\mathrm{TdR}\right)$ [52]. CMM thickness appeared correlated with the proportion of CMM cells in the S-phase of proliferation. The higher ${ }^{3} \mathrm{H}-\mathrm{TdR}$ indexes were found in metastases.

The M-phase has long attracted attention in CMM. On a descriptive ground, finding mitotic figures in the deep portion of a melanocytic neoplasm was considered to be suggestive for CMM. Quantitative assessments were used to derive a prognostic factor $(\mathrm{PF})$ following $\mathrm{PF}=M^{*}$ tumor thickness where $M$ represented the number of mitosis per $\mathrm{mm}^{2}$ [53]. More recently, a revival of mitosis interest emerged in CMM [54-56] and in melanocytic nevi as well [57]. Currently, it is possible to highlight mitoses using 
immunohistochemistry directed to specific $M$-associated histones. Indeed, DNA is wrapped around histone octamers to form the basic unit of chromatin structure. The octamer is composed of histones $\mathrm{H} 2 \mathrm{~A}, \mathrm{H} 2 \mathrm{~B}, \mathrm{H} 3$, and $\mathrm{H} 4$, and it associates with approximately 200 base pairs of DNA to form the nucleosome. Histone $\mathrm{H} 3$, the core protein of the nucleosome, becomes phosphorylated. The two major sites of phosphorylation are the M-specific site Ser 10 and Ser 28, both of which are extensively phosphorylated in DNA-bound forms of histone $\mathrm{H} 3$ and in nucleosomal histone $\mathrm{H} 3$. The phistone H3 (Ser 10)-R detects Ser 10 phosphorylated histone H3 $[58,59]$.

\section{CMM Stem Cells}

In the past decades, CMM evolution was commonly described as the result of a "dedifferentiation" process of transformed mature melanocytes, enabling a stepwise metamorphosis starting from the radial growth phase, evolving toward the vertical growth phase, and ultimately leading to the disseminated disease. More recently, the heterogeneity and plasticity of the CMM cell populations led to the cancer stem cell (CSC) concept [60-67]. The regular stem cells of the melanocytic lineage are present in the human hair follicle, the epidermis, and the dermis [18, 68, 69]. The mutated melanocyte stem cells or immature melanocytic progenitor cells present in the skin were considered as possible precursors to CMM [17, 18, 20, 64].

CSCs, also referred to as tumor-initiating cells, were initially identified in several hematological malignancies and several solid cancers $[60,65]$. Similar to physiologic postnatal stem cells, CSCs are capable of self-renewal and differentiation, and they are potentially involved in a perpetual selfrenewal, a function sustaining unlimited tumor growth [61]. Although conventional anticancer treatments eradicate most of the target malignant cells, such drugs are typically inactive against chemoresistant CSC. This failure is ultimately responsible for neoplastic recurrence and progression. CMM exhibits cell heterogeneity, various molecular signatures, variable plasticity, and prominent tumorigenicity of some CMM cell subsets. These features are probably related to the involvement of CSC in the initiation and progression of the neoplasm [17-23, 61-67].

Embryonic and postnatal physiologic stem cells are capable of self-renewal at a slow cycling rate ensuring perpetual but discrete proliferation [61]. In addition, the multipotent stem cells possibly differentiate into cell types of multiple lineages, whereas unipotent stem cell give rise to a single lineage $[17-19,60]$. The stem-cell-derived cancer model purports that most cancers are composed of relatively few CSCs steadily undergoing self-renewal, thereby maintaining a lifelong CSC pool. In addition, some other CSCs differentiate into fast-growing transient amplifier cells or progenitor cells, that in turn differentiate into mature cancer cells with limited proliferative potential $[23,70]$. The latter cells form the bulk of the neoplastic GF in the primary CMM and its metastases.

Each CMM exhibits genetic and phenotypic heterogeneity, undifferentiated molecular signatures, and various developments of tumorigenicity and metastatic potential $[11,17,71]$. Primary CMM initiating cells appear restricted to CD133-positive (prominin-1) CSC, whereas CD133negative CMM cells apparently lack tumorigenicity [70]. The embryonic-like differentiation plasticity supports the concept of involvement of CMM stem cells in the neoplastic evolution, from tumor initiation to progression and metastasis [71]. In addition, CMM contain some CSC-associated proteins as well as progenitor cell-specific molecules including cancer testis antigens [72] and bone morphogenetic proteins [73]. Genetic aberrations in the signal-transduction machinery of CSC survival and differentiation contribute to both CMM progression and metastatic spreading. The similarity of self-renewal mechanisms between physiologic stem cells and CSC [74] is a further argument suggesting the involvement of melanocytic stem cells in the CMM pathogenesis.

Chemotherapy resistance of advanced CMM, particularly in its metastatic stage, possibly results from several mechanisms linked to CMM stem cell biology, including the impairment of CMM apoptotic pathways, a relative proliferation quiescence, and a restricted intracellular drug accumulation. In particular, CMM cell dormancy [75] and CMM recurrence following initial remission is possibly related to the inability of current drug regimens to eradicate the putative compartment of CMM stem cells [64, 76-78].

\section{Cyclins in CMM}

Three optional physiologic pathways conceptually govern the cell life. Accordingly, cells continuously proliferate, or survive without further divisions, or die following apoptosis. The decision for a cell to proceed through the proliferative cycle is taken at two cardinal restriction checkpoints corresponding to the commitment to DNA replication and the commitment to mitosis at completion of the $\mathrm{G}_{2}$-phase. Throughout the $\mathrm{G}_{1}$-phase, a number of growth factors influence the cell fate through binding to specific surface receptors. This process results in cell differentiation or proliferation following activation of a signalling cascade regulating the transcription of both immediate and delayed early response genes. Once cells have entered the S-phase, they become refractory to a series of growth-factor-induced stimuli. The next cell cycle events are controlled by an intrinsic programme regulating the progression through the $\mathrm{G}_{2}$ - and $\mathrm{M}$-phases.

Similarly to many other malignancies, CMM cells progress through deregulation of control mechanisms ruling both cell proliferation and escape from programmed apoptosis [79]. Each cell cycle step is normally controlled by the expression of a precise set of regulatory molecules. Heteroprotein dimers combining a protein kinase and a regulatory cyclin form the basic clockwork of the cell cycle progression. A series of cyclins bind and activate cyclindependent kinases. The diverse cyclins C, D1 (CCND1 gene product), D2, D3, and $\mathrm{E}$ as well as CDK2, p16 ${ }^{\mathrm{INK} 4 \mathrm{a}}$, $\mathrm{p} 21^{\mathrm{CIP} 1}$, and $\mathrm{p} 27^{\mathrm{KIP} 1}$ drive the cell cycle of proliferation in its progression during the $\mathrm{G}_{1}$ - to the S-phase. Cyclin A normally regulates the passage from the $S$ - to $G_{2}$-phase, and cyclin $B$ from the $\mathrm{G}_{2}$-phase to mitosis [80]. 
Melanocytic nevi rarely express cyclin A, B, D1, and D3. By contrast, these cyclins are commonly present in CMM [80]. In some CMM, a negative correlation was pointed out between cyclin A expression and the disease-free survival [81]. The cyclin B and D1 prognostic relevance remains unsettled in CMM. Of note, the GG-CCND1 mutation (A8706-CCND1 polymorphism) in peripheral blood cells represents a genetic predisposition for CMM. Increased cyclin D3 was reported to be associated with early relapse and decreased survival in thin CMM, but not in thicker CMM [82]. Cyclin E expression appeared to be negatively related with survival of CMM patients $[10,83]$.

Cyclin-dependent kinase inhibitors downregulate progression through the cell cycle of proliferation $[10,80]$. For instance, p16 normally inactivates cyclin D/CDK4 complexes in most melanocytic nevi [84-86]. By contrast, p16 expression is lost in most of the invasive, recurrent, and metastatic CMM [84-87]. This feature appears to be associated with decreased survival, although it does not seem to represent an independent prognostic parameter [80].

The p21 protein is rarely present in melanocytic nevi. By contrast, it shows increased immunoreactivity in CMM [88]. It inhibits cyclin/CDK complexes, binds to PCNA and thus, it inhibits DNA polymerase $\delta$ o. Any relationship between increased p21 immunoreactivity and CMM outcome remains unsettled.

The p27 protein inhibits both cyclin D/CDK4 and cyclin E/CDK2 complexes. Thus, it blocks the cell cycle progression from the $G_{1}$ - to $S$-phase $[89,90]$. A clear p27 expression distinction is not established between melanocytic nevi and CMM. Thick CMM with a p27 index lower than 5\% might be at increased risk for early relapse. However, the magnitude in p27 expression has no effect on the overall survival [88].

The p53 gene is commonly mutated in cancers. The normal wild-type $\mathrm{p} 53$ protein is a $53-\mathrm{kDa}$ tumor suppressor protein blocking the cell cycle at both the $\mathrm{G}_{1}$ - and $\mathrm{G}_{2}$ phases, allowing repair of the DNA damage [91]. In addition, p53 induces the expression of p21 contributing to inhibit DNA synthesis [88]. Mutations of the p53 gene produce abnormal p53 proteins unable to inhibit the cell cycle. As the regular p53 protein is short lived, it is not detected using immunohistochemistry. By contrast, the long-lived mutated p53 protein is conveniently disclosed using immunohistochemistry. Accordingly, p53 protein is not revealed in most melanocytic nevi, but is present in its mutated form in 25-60\% of CMM $[14,88,91-93]$. Overexpression of the $\mathrm{p} 53$ protein was reported in CMM originating from a precursor p53-negative melanocytic nevus [92]. Some benign melanocytomas show nearly $10 \%$ cell positivity for the mutated p53 protein [94]. A correlation was disclosed between p53 expression and thicker CMM [95]. However, no correlation was found between p53 immunoreactivity and likelihood of metastasis, recurrence, and global CMM survival.

HDM2 is a $90-\mathrm{kDa}$ zinc finger protein that binds to the transcription activation domain of the p53 gene [96, 97]. Increased HDM2 immunostaining might represent an independent prognostic factor paradoxically associated with decreased recurrence rates and increased survival in CMM [97].

\section{Mitogen-Activated Protein Kinase Pathway in CMM}

Gene expression profiles characterize cells from any given tissue. Alterations of these patterns potentially disrupt cell homeostasis leading to some diseases including cancer. Compared to regular melanocytes, a number of primary and secondary mutations were reported in advanced CMM. A primary clonal event in neoplastic progression possibly contributes to the malignancy. This process is possibly based on a genetic origin (gene mutation, deletion, amplification, or translocation). Such defect occurs independently, rather than as a secondary event following some other oncogenic changes. Alternatively, epigenetic alterations possibly result from heritable changes generally corresponding to transcriptional modulation following DNA methylation, and/or by chromatin alterations resulting from histone alteration. Clonal evolution of cancer initiates new clones exhibiting growth advantage over other cells, or an alternative selective advantage such as migration potential [98].

The gene products subject to primary clonal alterations in CMM correspond to activated or amplified genes, and conversely to other inactivated or deleted genes. Hundreds of secondary changes were described in CMM [99-103]. However, there are limitations to the interpretations of reported data. Indeed, genes were often tested only for mutations, rather than for deletions or amplifications. Hence, frequencies of aberration are probably underestimated [16]. In addition, some studies focused on cell lines, while others used uncultured native tissues. Both procedures commonly provided different results.

A number of signalling pathways are critical to the survival and growth of CMM cells. The most important pathway is the mitogen-activated protein kinase (MAPK) cascade. It includes the MAPK kinase (MEK) which is just downstream BRAF, the extracellular signal-regulated protein kinase (ERK), and the p38 MAPK and the Jun NH2-terminal protein kinase (JNK) activation pathways [104]. MAPK activation is linked to the induction of the transcription factor AP-1 regulating the expression of a series of genes involved in the regulation of both cell growth and differentiation. The MAPK pathway is activated and altered in nearly all CMM. It is involved in the neoplastic proliferation, invasion, and survival $[105,106]$ through the RAS/RAF/MEK/ERK signal transduction pathway regulating cell growth.

MAPK signalling is initiated at the cell membrane, either by tyrosine kinases (RTKs) binding ligand or by integrin adhesion to the extracellular matrix. This latter event activates the RAS-GTPase at the cell membrane inner surface $[107,108]$. GTP-bound RAS binds effector proteins, boosting cell proliferation, differentiation, and survival through activation of various signalling pathways [108]. RAF and phosphatidylinositol 3-kinase (PI3K) are well-characterized RAS effector proteins.

The RAF protein family is composed of serine/threonine kinases. It includes three proteins, ARAF, BRAF, and CRAF 
(corresponding to RAF-1) coded by unique genes [109111]. Any RAF family member activates the MAPK pathway, although each isoform possesses a distinct expression profile with unique phosphorylation targets and signalling effects [110]. RAF is the primary link between RAS and the MAPK pathway. RAF has long been identified as a protooncogene [112]. It activates the cascade of proliferative or survival signals through phosphorylation of a number of cytoplasmic targets $[14,113]$.

Over 50 BRAF mutations have been identified inside the kinase domain. The most common is the replacement of glutamic acid by valine in the position 600 , the so-called V600E BRAF mutation [114-117]. This single aminoacid substitution accounts for $80-90 \%$ of the BRAF gene mutations $[109,112,118-121]$. In addition, RAS is mutated in approximately $15 \%$ of cancers including CMM [109]. The V600E mutant expresses a 10-fold increased kinase activity compared to the wild-type BRAF [109].

BRAF is mutated in about $7-30 \%$ of human cancers, but this mutation is present in almost $60-80 \%$ of CMM [107$111,113,119,122]$. BRAF mutations were found in a number of melanocytic nevi as well $[109,120,121]$. The presence of BRAF mutations in melanocytic nevi suggests that a single BRAF mutation in the MAPK pathway as found in CMM is probably inadequate to promote malignant transformation $[109,119,120,123,124]$. Rather a single BRAF mutation appears to represent a senescence factor in melanocytes and melanocytic nevi [124]. Another oncogenic hit is therefore necessary including the interaction of BRAF with PTEN [125], p16 [124], p53 [123], AKT [126], and UV radiation [127]. The NRAS and BRAF mutations present in CMM exhibit some characteristic UV radiation-induced changes. The target of UV injury leading to such mutations remains unclear [113, 128].

Clearly, histopathologic assessments point to the fact that the majority of CMM occur outside a precursor melanocytic lesion [128]. In general, CMM originating from a melanocytic nevus exhibit both a BRAF mutation or are both negative for the mutation $[129,130]$.

In primary CMM, the genomewide alterations in DNA copy number, as well as BRAF and NRAS mutations [131], suggest the role of BRAF kinase both in CMM development and CMM heterogeneity [14]. Increased BRAF mutations are found in both nodular and superficial spreading CMM, contrasting with acral lentiginous CMM, lentigo maligna, and mucosal CMM [132-134]. CMM with the highest prevalence of BRAF mutations were those associated with intermittent sun exposure [132]. This relationship reveals a stringent relationship between sporadic UV exposure, BRAF/NRAS mutations, and additional genetic events in CMM [80, 122]. CMM without either mutation often exhibit increased copies of CDK4 or CCND1. Furthermore, no CMM with CDK4 amplification exhibited concomitant NRAS or BRAF mutations, or CCND1 amplification. Such finding suggests overlapping functions of the MAPK pathway and the CCND1/CDK4 pathways with independent oncogenic functions. The overall incidence of BRAF and NRAS mutations was significantly lower in CMM developed on chronic sun-damaged (CSD) skin as well as on sun-shielded sites, with BRAF and NRAS mutations being mutually exclusive. The CMM thickness had apparently no influence on frequency of mutation in BRAF or NRAS, or amplification (CCND1 or CDK4). In CMM developed on CSD, BRAF mutations were rare and CCND1 copy gain predominated [135]. Conversely, in CMM developed outside CSD, mutant BRAF and chromosome 10 (site of PTEN) loss were both common.

An important link between germline mutations of the melanocortin-1 receptor (MC1R) and BRAF mutations is possible [136]. Although MC1R variants were identified as risk factors for CMM [137], the precise link to sun exposure and genetic events in primary CMM remains unclear. MC1R variant alleles were found to be associated with CMM risk, specifically in CMM developed outside CSD. Such risk was associated with neoplasms harbouring BRAF mutations suggesting that germline events largely influenced genetic events leading to tumorigenesis in response to environmental UV exposures.

The enhancement of mitogenic activity in skin cancers is possibly reflected by the difference of intrinsic mitogenic signalling pathways [138]. A signalling pathway involves activation of the MAPK family, whose molecular components play a complex role in the determination of cell growth. It appears that p38 MAPK is activated by UV irradiation, cytokines, hormones, and some stresses such as osmotic shock and heat shock. Its prognostic value is possible in some malignancies [139].

\section{Apoptosis in CMM}

Programmed cell death or apoptosis is different in its selfdestruction from necrotic cell death. It represents one major mechanism involved in reducing the expansile growth of melanocytic neoplasms. As a functional counterpart of mitosis, apoptosis plays a crucial role and is normally firmly regulated. Apoptosis is altered in melanocytic neoplasms when the components and regulators of the cellular apoptotic machinery are mutated or present in inappropriate amounts. In CMM, the molecular apoptosis machinery includes positive (proapoptotic) and negative (antiapoptotic) regulators [140-143]. The former includes p53, Bid, Noxa, PUMA, Bax, TNF $\alpha$, TRAIL, Fas/FasL, PITSLRE, interferons (IFN), and $\mathrm{c}-\mathrm{KIT} / \mathrm{SCF}$. The antiapoptotic regulators include $\mathrm{Bcl}-2$, Bcl- $\mathrm{X}_{\mathrm{L}}, \mathrm{Mcl}-1, \mathrm{NF}_{\mathrm{K}} \mathrm{B}$, survivin, livin, AKT, and ML-LAP $[91,94,144]$. Alternatively, some molecules such as TRAF2, c-Myc, endothelin, and integrins either exhibit pro- or antiapoptotic effects. In addition, the PI3K pathway is activated following the biding of a ligand to a receptor tyrosine kinase (RTK). It interacts with multiple cellular mechanisms of apoptosis, survival, proliferation, mobility, differentiation, and growth. The phosphatase and tensin homolog (PTEN) is a tumor suppressor gene. Its protein product inhibits CMM growth and increases its susceptibility to apoptosis [145]. The deletion or silencing of PTEN increases the level of AKT3 phosphorylation in melanocytes and early-stage CMM cells.

A small CMM subset (2 to 5\%) presents amplification or mutation in c-Kit. It is more frequent in sun-shielded areas, 
such as in the mucous and acral CMM types, although it can be found on CSD areas [146, 147].

$\mathrm{Bcl}-2$ is a protooncogene that is not involved in the mechanisms of cell proliferation, but instead influences tissue homeostasis regulated by apoptosis. The gene encodes for a protein that preserves cells from apoptosis, allowing them to survive in $\mathrm{G}_{0}$-phase even in the absence of essential growth factors. The Bcl-2 protein is conveniently detected using immunohistochemistry. It is expressed in most CMM and melanocytic nevi [148] suggesting that its expression is a common finding in cutaneous melanocytic tumors regardless of their biologic behavior. Expression of the Bcl-2 protein in the vast majority of CMM rules out any prognostic significance of Bcl-2 in CMM.

Some of the apoptosis-related molecules are of potential therapeutic use, including (a) p53, which influences resistance to chemotherapy, (b) Mcl-1 and Bcl- $\mathrm{X}_{\mathrm{L}}$, which override apoptosis, (c) TRAIL, which has selective fatal effects on neoplastic cells, (d) downregulated $\mathrm{NF}_{-\mathrm{K}} \mathrm{B}$, which sensitizes cells to TRAIL and TNF, (e) PITSLRE kinases, whose alteration appears to result in Fas resistance, (f) IFN sensitizing cells to other factors, and (g) survivin that inhibits apoptosis.

Impaired regulation of apoptosis is associated with the development of various cancers. Fas binding to its ligand, Fas ligand (Fas-L), is expressed by CMM cells and plays a role in tumoral escape from immune surveillance [141, 149]. Apoptotic activity appeared minimal in CMM and moderate in Spitz melanocytomas. By contrast, melanocytic nevi demonstrated more intense apoptosis in the deep portion of the tumor. Fas was found to be expressed by all Spitz melanocytomas, most melanocytic nevi, and approximately half of the CMM. Fas expression was significantly more pronounced in Spitz melanocytomas as compared with the two other neoplasms. Fas-L was shown to be more expressed and more frequent in CMM cells as compared to nevus cells.

\section{Conclusion}

When CMM frequency emerged a few decades ago, dermatologists, dermatopathologists, and oncologists clearly underestimated the impact and relevance of CMM cell proliferation including CMM stem cells. These limitations were obstacles to tackling CMM beyond the stage of the primary neoplasm often curable by surgery alone. With the improvement of dermatopathology and molecular biology beyond routine histopathology, skilled researchers were able to better assess the neoplastic CMM progression. They tackled many facets of CMM with both increased knowledge and the benefit of hindsight. There is evidence that future CMM treatments will target some specific molecular steps of the neoplastic cell cycle of proliferation and the apoptosis pathways.

The links between the clinical evolution, cell proliferation/apoptosis, and key molecular aberrations are progressively elucidated in CMM. These advances represent key factors supporting the identification and distinction of different CMM types, including the growth-stunted, the slow-growing accretive growth and the fast-growing expansile proliferative neoplasms.

\section{Acknowledgments}

This work was supported by a grant from the "Fonds d'Investissement de la Recherche Scientifique" of the University Hospital of Liège. No other sources of funding were used to assist in the preparation of this paper. No conflict of interests is directly relevant to the content of this paper. The author's colleagues Professor C. Franchimont and P. Quatresooz are granted for their help in the preparation of this paper. The author appreciates the technical skill of G. Currenti and J. Espinosa Perez and the excellent secretarial assistance of Mrs. Ida Leclercq and Marie Pugliese.

\section{References}

[1] I. Uhoda, P. Quatresooz, I. Fumal, A. F. Nikkels, C. PiérardFranchimont, and G. E. Piérard, "Updating trends in cutaneous cancers in south-east Belgium," Oncology Reports, vol. 12, no. 1, pp. 111-114, 2004.

[2] A. Jemal, R. Siegel, E. Ward, T. Murray, J. Xu, and M. J. Thun, "Cancer statistics," A Cancer Journal for Clinicians, vol. 57, no. 1, pp. 43-66, 2007.

[3] A. Verdecchia, S. Francisci, H. Brenner et al., "Recent cancer survival in Europe: a 2000-02 period analysis of EUROCARE-4 data," Lancet Oncology, vol. 8, no. 9, pp. 784796, 2007.

[4] N. Crowson, C. M. Magro, and M. C. Mihm, "Prognosticators of melanoma, the melanoma report, and the sentinel lymph node," Modern Pathology, vol. 19, no. 2, pp. S71-S87, 2006.

[5] B. R. Smoller, "Histologic criteria for diagnosing primary cutaneous malignant melanoma," Modern Pathology, vol. 19, no. 2, pp. S34-S40, 2006.

[6] L. Brochez, E. Verhaeghe, E. Grosshans et al., "Inter-observer variation in the histopathological diagnosis of clinically suspicious pigmented skin lesions," Journal of Pathology, vol. 196, no. 4, pp. 459-466, 2002.

[7] P. Quatresooz, J. E. Arrese, C. Pierard-Franchimont, and G. E. Pierard, "Immunohistochemical aid at risk stratification of melanocytic neoplasms," International Journal of Oncology, vol. 24, no. 1, pp. 211-216, 2004.

[8] N. Claessens, G. E. Piérard, C. Piérard-Franchimont, J. E. Arrese, and P. Quatresooz, "Immunohistochemical detection of incipient melanoma micrometastases. Relationship with sentinel lymph node involvement," Melanoma Research, vol. 15, no. 2, pp. 107-110, 2005.

[9] J. A. Plaza, D. Suster, and D. Perez-Montiel, "Expression of immunohistochemical markers in primary and metastatic malignant melanoma: a comparative study in 70 patients using a tissue microarray technique," Applied Immunohistochemistry and Molecular Morphology, vol. 15, no. 4, pp. 421425, 2007.

[10] S. J. Ohsie, G. P. Sarantopoulos, A. J. Cochran, and S. W. Binder, "Immunohistochemical characteristics of melanoma," Journal of Cutaneous Pathology, vol. 35, no. 5, pp. 433444, 2008.

[11] P. Quatresooz, C. Piérard-Franchimont, and G. E. Piérard, "Highlighting the immunohistochemical profile of melanocytomas," Oncology Reports, vol. 19, no. 6, pp. 1367-1372, 2008.

[12] P. Quatresooz, C. Pierard-Franchimont, A. Rorive et al., "Molecular histology on the diagnostic cutting edge between 
malignant melanomas and cutaneous melanocytomas," Oncology Reports, vol. 22, no. 6, pp. 1263-1267, 2009.

[13] J. A. Carlson, J. S. Ross, A. Slominski et al., "Molecular diagnostics in melanoma," Journal of the American Academy of Dermatology, vol. 52, no. 5, pp. 743-775, 2005.

[14] L. A. Fecher, S. D. Cummings, M. J. Keefe, and R. M. Alani, "Toward a molecular classification of melanoma," Journal of Clinical Oncology, vol. 25, no. 12, pp. 1606-1620, 2007.

[15] T. Schatton, G. F. Murphy, N. Y. Frank et al., "Identification of cells initiating human melanomas," Nature, vol. 451, no. 7176, pp. 345-349, 2008.

[16] M. A. Reginster, C. Piérard-Franchimont, G. E. Piérard et al., "Molecular dermatopathology in malignant melanoma," Dermatology Research and Practice, vol. 2012, Article ID 684032, 6 pages, 2012.

[17] D. Fang, T. K. Nguyen, K. Leishear et al., "A tumorigenic subpopulation with stem cell properties in melanomas," Cancer Research, vol. 65, no. 20, pp. 9328-9337, 2005.

[18] J. M. Grichnik, J. A. Burch, R. D. Schulteis et al., "Melanoma, a tumor based on a mutant stem cell?" Journal of Investigative Dermatology, vol. 126, no. 1, pp. 142-153, 2006.

[19] K. Buac and W. J. Pavan, "Stem cells of the melanocyte lineage," Cancer Biomarkers, vol. 3, no. 4-5, pp. 203-209, 2007.

[20] W. M. Klein, B. P. Wu, S. Zhao, H. Wu, A. J. P. Klein-Szanto, and S. R. Tahan, "Increased expression of stem cell markers in malignant melanoma," Modern Pathology, vol. 20, no. 1, pp. 102-107, 2007.

[21] T. Schatton and M. H. Frank, "Cancer stem cells and human malignant melanoma," Pigment Cell and Melanoma Research, vol. 21, no. 1, pp. 39-55, 2007.

[22] G. Rappa, O. Fodstad, and A. Lorico, "The stem cell-associated antigen CD133 (Prominin-1) is a molecular therapeutic target for metastatic melanoma," Stem Cells, vol. 26, no. 12, pp. 3008-3017, 2008.

[23] P. Quatresooz, G. E. Pierard, C. Pierard-Franchimont et al., "Molecular pathways supporting the proliferation staging of malignant melanoma," International Journal of Molecular Medicine, vol. 24, no. 3, pp. 295-301, 2009.

[24] P. Quatresooz and G. E. Piérard, "Malignant melanoma: from cell kinetics to micrometastases," American Journal of Clinical Dermatology, vol. 12, no. 2, pp. 77-86, 2011.

[25] D. C. Bodenham, "A study of 650 observed malignant melanomas in the South-West region," Annals of the Royal College of Surgeons of England, vol. 43, no. 4, pp. 218-239, 1968.

[26] L. Holmgren, M. S. O'Reilly, and J. Folkman, “Dormancy of micrometastases: balanced proliferation and apoptosis in the presence of angiogenesis suppression," Nature Medicine, vol. 1, no. 2, pp. 149-153, 1995.

[27] G. E. Piérard, C. Piérard-Franchimont, M. A. Reginster et al., "Smouldering malignant melanoma and metastatic dormancy. An update and review," Dermatology Research and Practice, vol. 2012, Article ID 461278, 6 pages, 2012.

[28] A. Mantovani, "Molecular pathways linking inflammation and cancer," Current Molecular Medicine, vol. 10, no. 4, pp. 369-373, 2010.

[29] P. E. Goss and A. F. Chambers, "Does tumour dormancy offer a therapeutic target?" Nature Reviews Cancer, vol. 10, no. 12, pp. 871-877, 2010.

[30] Z. J. Yang, C. Chee, S. Huang, and F. Sinicrope, "Autophagy modulation for cancer therapy," Cancer Biology and Therapy, vol. 11, no. 2, pp. 169-176, 2011.
[31] J. Eyles, A. L. Puaux, X. Wang et al., "Tumor cells disseminate early, but immunosurveillance limits metastatic outgrowth, in a mouse model of melanoma," Journal of Clinical Investigation, vol. 120, no. 6, pp. 2030-2039, 2010.

[32] M. Rocken, "Early tumor dissemination, but late metastasis: insights into tumor dormancy," Journal of Clinical Investigation, vol. 120, no. 6, pp. 1800-1803, 2010.

[33] H. P. Soyer, "Ki67 immunostaining in melanocytic skin tumors. Correlation with histologic parameters," Journal of Cutaneous Pathology, vol. 18, no. 4, pp. 264-272, 1991.

[34] C. Piérard-Franchimont, J. E. Arrese, A. F. Nikkels, W. AlSaleh, P. Delvenne, and G. E. Piérard, "Factor XIIIa-positive dendrocytes and proliferative activity of cutaneous cancers," Virchows Archiv, vol. 429, no. 1, pp. 43-48, 1996.

[35] L. A. I. Talve, Y. U. I. Collan, and T. O. Ekfors, "Nuclear morphometry, immunohistochemical staining with Ki-67 antibody and mitotic index in the assessment of proliferative activity and prognosis of primary malignant melanomas of the skin," Journal of Cutaneous Pathology, vol. 23, no. 4, pp. 335-343, 1996.

[36] L. E. Sparrow, D. R. English, J. M. Taran, and P. J. Heenan, "Prognostic significance of MIB-1 proliferative activity in thin melanomas and immunohistochemical analysis of MIB1 proliferative activity in melanocytic tumors," American Journal of Dermatopathology, vol. 20, no. 1, pp. 12-16, 1998.

[37] A. Niezabitowski, K. Czajecki, J. Rys et al., "Prognostic evaluation of cutaneous malignant melanoma: a clinicopathologic and immunohistochemical study," Journal of Surgical Oncology, vol. 70, no. 3, pp. 150-160, 1999.

[38] P. Quatresooz, C. Pierard-Franchimont, P. Paquet, and G. E. Pierard, "Angiogenic fast-growing melanomas and their micrometastases," European Journal of Dermatology, vol. 20, no. 3, pp. 302-307, 2010.

[39] A. Väisänen, P. Kuvaja, M. Kallioinen, and T. TurpeenniemiHujanen, "A prognostic index in skin melanoma through the combination of matrix metalloproteinase-2, Ki67, and p53," Human Pathology, vol. 42, no. 8, pp. 1103-1111, 2011.

[40] D. Lipsker, "Growth rate, early detection, and prevention of melanoma: melanoma epidemiology revisited and future challenges," Archives of Dermatology, vol. 142, no. 12, pp. 1638-1640, 2006.

[41] W. Liu, J. P. Dowling, W. K. Murray et al., "Rate of growth in melanomas: characteristics and associations of rapidly growing melanomas," Archives of Dermatology, vol. 142, no. 12, pp. 1551-1558, 2006.

[42] D. Lipsker, F. Engel, B. Cribier, M. Velten, and G. Hedelin, "Trends in melanoma epidemiology suggest three different types of melanoma," British Journal of Dermatology, vol. 157, no. 2, pp. 338-343, 2007.

[43] R. MacKie, C. Bray, J. Vestey et al., "Melanoma incidence and mortality in Scotland 1979-2003," British Journal of Cancer, vol. 96, no. 11, pp. 1772-1777, 2007.

[44] I. Zalaudek, A. A. Marghoob, A. Scope et al., "Three roots of melanoma," Archives of Dermatology, vol. 144, no. 10, pp. 1375-1379, 2008.

[45] R. Boni, A. Doguoglu, G. Burg et al., "MIB-1 immunoreactivity correlates with metastatic dissemination in primary thick cutaneous melanoma," Journal of the American Academy of Dermatology, vol. 35, no. 3, pp. 416-418, 1996.

[46] G. E. Piérard and C. Piérard-Franchimont, "Stochastic relationship between the growth fraction and vascularity of thin malignant melanomas," European Journal of Cancer, vol. 33, no. 11, pp. 1888-1892, 1997. 
[47] C. Piérard-Franchimont, F. Henry, O. Heymans, and G. E. Piérard, "Vascular retardation in dormant growth-stunted malignant melanomas," International Journal of Molecular Medicine, vol. 4, no. 4, pp. 403-406, 1999.

[48] O. Straume, L. Sviland, and L. A. Akslen, "Loss of nuclear p16 protein expression correlates with increased tumor cell proliferation (Ki-67) and poor prognosis in patients with vertical growth phase melanoma," Clinical Cancer Research, vol. 6, no. 5, pp. 1845-1853, 2000.

[49] S. O. Frahm, C. Schubert, R. Parwaresch, and P. Rudolph, "High proliferative activity may predict early metastasis of thin melanomas," Human Pathology, vol. 32, no. 12, pp. 1376-1381, 2001.

[50] P. Quatresooz, P. Paquet, T. Hermanns-Lê, and G. E. Piérard, "Molecular mapping of factor XIIIa-enriched dendrocytes in the skin," International Journal of Molecular Medicine, vol. 22, no. 4, pp. 403-409, 2008.

[51] P. Quatresooz, M. A. Reginster, and G. E. Piérard, "The 'malignant melanoma microecosystem': immunohistopathological insights into the stromal cell phenotype. A review," Experimental and Therapeutic Medicine, vol. 2, no. 3, pp. 379$384,2011$.

[52] G. E. Pierard, C. Pierard-Franchimont, C. Henry, and M. Lapiere, "The proliferative activity of cells of malignant melanomas," American Journal of Dermatopathology, vol. 6, no. 1, pp. S317-S323, 1984.

[53] C. Schmoeckel and O. Braun-Falco, "Prognostic index in malignant melanoma," Archives of Dermatology, vol. 114, no. 6, pp. 871-873, 1978.

[54] B. J. Averbook, "Mitotic rate and sentinel lymph node tumor burden topography: integration into melanoma staging and stratification use in clinical trials," Journal of Clinical Oncology, vol. 29, no. 16, pp. 2137-2141, 2011.

[55] H. Bösmüller, S. Haitchi-Petnehazy, T. Hintringer et al., "Mitosis in early invasive malignant melanoma: how reliable is histogenetic classification at stage pT1?" Pathologie. In press.

[56] J. F. Thompson, S.-J. Soong, C. M. Balch et al., "Prognostic significance of mitotic rate in localized primary cutaneous melanoma: an analysis of patients in the multi-institutional american joint committee on cancer melanoma staging database," Journal of Clinical Oncology, vol. 29, no. 16, pp. 2199-2205, 2011.

[57] S. M. Ruhoy, S. E. Kolker, and T. C. Murry, "Mitotic activity within dermal melanocytes of benign melanocytic nevi: a study of 100 cases with clinical follow-up," American Journal of Dermatopathology, vol. 33, no. 2, pp. 167-172, 2011.

[58] K. Shibata, M. Inagaki, and K. Ajiro, "Mitosis-specific histone H3 phosphorylation in vitro in nucleosome structures," European Journal of Biochemistry, vol. 192, no. 1, pp. 87-93, 1990.

[59] T. K. Fung, T. M. Hoi, and R. Y. C. Poon, "Specialized roles of the two mitotic cyclins in somatic cells: cydin A as an activator of M phase-promoting factor," Molecular Biology of the Cell, vol. 18, no. 5, pp. 1861-1873, 2007.

[60] T. Reya, S. J. Morrison, M. F. Clarke, and I. L. Weissman, "Stem cells, cancer, and cancer stem cells," Nature, vol. 414, no. 6859, pp. 105-111, 2001.

[61] M. Dean, T. Fojo, and S. Bates, "Tumour stem cells and drug resistance," Nature Reviews Cancer, vol. 5, no. 4, pp. 275-284, 2005.

[62] J. M. Topczewska, L. M. Postovit, N. V. Margaryan et al., "Embryonic and tumorigenic pathways converge via Nodal signaling: role in melanoma aggressiveness," Nature Medicine, vol. 12, no. 8, pp. 925-932, 2006.

[63] E. Wang, S. Voiculescu, I. C. Le Poole et al., "Clonal persistence and evolution during a decade of recurrent melanoma," Journal of Investigative Dermatology, vol. 126, no. 6, pp. 13721377, 2006.

[64] E. Monzani, F. Facchetti, E. Galmozzi et al., "Melanoma contains CD133 and ABCG2 positive cells with enhanced tumourigenic potential," European Journal of Cancer, vol. 43, no. 5, pp. 935-946, 2007.

[65] A. Schreder, G. E. Piérard, P. Paquet, M. A. Reginster, C. Pierard-Franchimont, and P. Quatresooz, "Facing towards epidermal stem cells," International Journal of Molecular Medicine, vol. 26, no. 2, pp. 171-174, 2010.

[66] S. Chandrasekaran and L. A. Delouise, "Enriching and characterizing cancer stem cell sub-populations in the WM115 melanoma cell line," Biomaterials, vol. 32, pp. 9316-9327, 2011.

[67] R. P. Shanesmith, C. Smart, D. S. Cassarino et al., "Tissue microarray analysis of ezrin, KBA62, CD166, nestin, and p-Akt in melanoma versus banal and atypical nevi, and non melanocytic lesions," The American Journal of Dermatopathology, vol. 33, no. 7, pp. 663-668, 2011.

[68] C. E. Wong, C. Paratore, M. T. Dours-Zimmermann et al., "Neural crest-derived cells with stem cell features can be traced back to multiple lineages in the adult skin," Journal of Cell Biology, vol. 175, no. 6, pp. 1005-1015, 2006.

[69] H. Yu, D. Fang, S. M. Kumar et al., "Isolation of a novel population of multipotent adult stem cells from human hair follicles," American Journal of Pathology, vol. 168, no. 6, pp. 1879-1888, 2006.

[70] J. G. Toma, M. Akhavan, K. J. Fernandes et al., "Isolation of multipotent adult stem cells from the dermis of mammalian skin," Nature Cell Biology, vol. 3, no. 9, pp. 778-784, 2001.

[71] M. J. Hendrix, E. A. Seftor, A. R. Hess, and R. E. B. Seftor, "Vasculogenic mimicry and tumour-cell plasticity: lessons from melanoma," Nature Reviews Cancer, vol. 3, no. 6, pp. 411-421, 2003.

[72] A. J. Simpson, O. L. Caballero, A. Jungbluth, Y. T. Chen, and L. J. Old, "Cancer/testis antigens, gametogenesis and cancer," Nature Reviews Cancer, vol. 5, no. 8, pp. 615-625, 2005.

[73] T. Rothhammer, F. Bataille, T. Spruss, G. Eissner, and A. K. Bosserhoff, "Functional implication of BMP4 expression on angiogenesis in malignant melanoma," Oncogene, vol. 26, no. 28, pp. 4158-4170, 2007.

[74] T. Reya and H. Clevers, "Wnt signalling in stem cells and cancer," Nature, vol. 434, no. 7035, pp. 843-850, 2005.

[75] S. J. Ralph, "An update on malignant melanoma vaccine research: insights into mechanisms for improving the design and potency of melanoma therapeutic vaccines," American Journal of Clinical Dermatology, vol. 8, no. 3, pp. 123-141, 2007.

[76] S. J. Ralph, "An update on malignant melanoma vaccine research: insights into mechanisms for improving the design and potency of melanoma therapeutic vaccines," American Journal of Clinical Dermatology, vol. 8, no. 3, pp. 123-141, 2007.

[77] A. M. Terando, M. B. Faries, and D. L. Morton, "Vaccine therapy for melanoma: current status and future directions," Vaccine, vol. 25, no. 2, pp. 4-16, 2007.

[78] P. Lorigan, T. Eisen, and A. Hauschild, "Systemic therapy for metastatic malignant melanoma-from deeply disappointing to bright future?" Experimental Dermatology, vol. 17, no. 5, pp. 383-394, 2008. 
[79] M. Malumbres and M. Barbacid, "To cycle or not to cycle: a critical decision in cancer," Nature Reviews Cancer, vol. 1, no. 3, pp. 222-231, 2001.

[80] J. Georgieva, P. Sinha, and D. Schadendorf, "Expression of cyclins and cyclin dependent kinases in human benign and malignant melanocytic lesions," Journal of Clinical Pathology, vol. 54, no. 3, pp. 229-235, 2001.

[81] V. A. Florenes, G. M. Maelandsmo, R. Faye et al., "Cyclin A expression in superficial spreading malignant melanomas correlates with clinical outcome," The Journal of Pathology, vol. 195, pp. 530-536, 2001.

[82] V. A. Florenes, G. M. Maelandsmo, R. S. Faye, J. M. Nesland, and R. Holm, "Levels of cyclin $\mathrm{d} 1$ and $\mathrm{d} 3$ in malignant melanoma: deregulated cyclin D3 expression is associated with poor clinical outcome in superficial melanoma," Clinical Cancer Research, vol. 6, no. 9, pp. 3614-3620, 2000.

[83] E. S. Bales, C. Deitrich, D. Bandyopadhyay et al., "High levels of expression of $\mathrm{p} 27^{\mathrm{KIPl}}$ and cyclin $\mathrm{E}$ in invasive primary malignant melanomas," Journal of Investigative Dermatology, vol. 113, pp. 1039-1046, 1999.

[84] L. Talve, I. Sauroja, Y. Collan, K. Punnonen, and T. Ekfors, "Loss of expression of the $\mathrm{p} 16^{\mathrm{INK} 4} / \mathrm{CDKN} 2$ gene in cutaneous malignant melanoma correlates with tumor cell proliferation and invasive stage," International Journal of Cancer, vol. 74, no. 3, pp. 255-259, 1997.

[85] S. J. Pavey, M. C. Cummings, D. C. Whiteman et al., "Loss of p16 expression is associated with histological features of melanoma invasion," Melanoma Research, vol. 12, no. 6, pp. 539-547, 2002.

[86] I. M. Bachmann, O. Straume, and L. A. Akslen, "Altered expression of cell cycle regulators Cyclin D1, p14, p16, CDK4 and $\mathrm{Rb}$ in nodular melanomas," International Journal of Oncology, vol. 25, no. 6, pp. 1559-1565, 2004.

[87] L. A. Fearfield, J. M. G. Larkin, A. Rowe et al., "Expression of p16, CD95, CD95L and Helix pomatia agglutinin in relapsing and nonrelapsing very thin melanoma," British Journal of Dermatology, vol. 156, no. 3, pp. 440-447, 2007.

[88] J. M. Karjalainen, M. J. Eskelinen, J. K. Kellokoski, M. Reinikainen, E. M. Alhava, and V.-M. Kosma, "P21 $1_{\text {WAF1/CIP1 }}$ expression in stage I cutaneous malignant melanoma: its relationship with p53, cell proliferation and survival," British Journal of Cancer, vol. 79, no. 5-6, pp. 895-902, 1999.

[89] V. A. Florenes, G. M. Maelandsmo, R. S. Kerbel et al., "Protein expression of the cell-cycle inhibitor p27 ${ }^{\mathrm{Kip} 1}$ in malignant melanoma: inverse correlation with disease-free survival," American Journal of Pathology, vol. 153, pp. 305-312, 1998.

[90] D. Ivan, A. H. Diwan, F. J. Esteva et al., "Expression of cell cycle inhibitor $\mathrm{p} 27^{\mathrm{Kip} 1}$ and its inactivator Jab1 in melanocytic lesions," Modern Pathology, vol. 17, pp. 811-818, 2004.

[91] M. Korabiowska, H. Betke, S. Kellner, J. Stachura, and A. Schauer, "Differential expression of growth arrest, DNA damage genes and tumour suppressor gene p53 in naevi and malignant melanomas," Anticancer Research, vol. 17, no. 5, pp. 3697-3700, 1997.

[92] J. M. Radhi, "Malignant melanoma arising from nevi, p53, p16, and Bcl-2: expression in benign versus malignant components," Journal of Cutaneous Medicine and Surgery, vol. 3, no. 6, pp. 293-297, 1999.

[93] B. A. Webber, D. Lawson, and C. Cohen, "Maspin and mutant p53 expression in malignant melanoma and carcinoma: use of tissue microarray," Applied Immunohistochemistry and Molecular Morphology, vol. 16, no. 1, pp. 19-23, 2008.
[94] J. A. Chorny, R. J. Barr, A. Kyshtoobayeva, J. Jakowatz, and R. J. Reed, "Ki-67 and p53 expression in minimal deviation melanomas as compared with other nevomelanocytic lesions," Modern Pathology, vol. 16, no. 6, pp. 525-529, 2003.

[95] B. Loggini, I. Rinaldi, R. Pingitore, R. Cristofani, M. Castagna, and P. Barachini, "Immunohistochemical study of 49 cutaneous melanomas: p53, PCNA, Bcl-2 expression and multidrug resistance," Tumori, vol. 87 , no. 3, pp. 179-186, 2001.

[96] D. Polsky, B. C. Bastian, C. Hazan et al., "HDM2 protein overexpression, but not gene amplification, is related to tumorigenesis of cutaneous melanoma," Cancer Research, vol. 61, no. 20, pp. 7642-7646, 2001.

[97] D. Polsky, K. Melzer, C. Hazen et al., "HDM2 protein overexpression and prognosis in primary malignant melanoma," Journal of the National Cancer Institute, vol. 94, no. 23, pp. 1803-1806, 2002.

[98] K. S. Hoek, N. C. Schlegel, P. Brafford et al., "Metastatic potential of melanomas defined by specific gene expression profiles with no BRAF signature," Pigment Cell Research, vol. 19, no. 4, pp. 290-302, 2006.

[99] K. S. Hoek, "DNA microarray analyses of melanoma gene expression: a decade in the mines," Pigment Cell Research, vol. 20, no. 6, pp. 466-484, 2007.

[100] J. A. Curtin, J. Fridlyand, T. Kageshita et al., "Distinct sets of genetic alterations in melanoma," The New England Journal of Medicine, vol. 353, no. 20, pp. 2135-2147, 2005.

[101] G. Jönsson, C. Dahl, J. Staaf et al., "Genomic profiling of malignant melanoma using tiling-resolution arrayCGH," Oncogene, vol. 26, no. 32, pp. 4738-4748, 2007.

[102] T. Rothhammer and A. K. Bosserhoff, "Epigenetic events in malignant melanoma," Pigment Cell Research, vol. 20, no. 2, pp. 92-111, 2007.

[103] M. Stark and N. Hayward, "Genome-wide loss of heterozygosity and copy number analysis in melanoma using high-density single-nucleotide polymorphism arrays," Cancer Research, vol. 67, no. 6, pp. 2632-2642, 2007.

[104] G. L. Johnson and R. Lapadat, "Mitogen-activated protein kinase pathways mediated by ERK, JNK, and p38 protein kinases," Science, vol. 298, no. 5600, pp. 1911-1912, 2002.

[105] H. Ihn, "p38 MAPK inhibitors in dermatology," Expert Review of Dermatology, vol. 2, no. 4, pp. 403-407, 2007.

[106] I. Yajima, M.Y. Kumasaka, N. Thang et al., "RAS/RAF/ MEK/ERK and P13K/PTEN/AKT signalling in malignant melanoma progression and therapy," Dermatology Research and Practice, vol. 2012, Article ID 354191, 5 pages, 2012.

[107] P. M. Campbell and C. J. Der, "Oncogenic Ras and its role in tumor cell invasion and metastasis," Seminars in Cancer Biology, vol. 14, no. 2, pp. 105-114, 2004.

[108] K. Giehl, "Oncogenic Ras in tumour progression and metastasis," Biological Chemistry, vol. 386, no. 3, pp. 193-205, 2005.

[109] H. Davies, G. R. Bignell, C. Cox et al., "Mutations of the BRAF gene in human cancer," Nature, vol. 417, no. 6892, pp. 949-954, 2002.

[110] M. Beeram, A. Patnaik, and E. K. Rowinsky, "Raf: a strategic target for therapeutic development against cancer," Journal of Clinical Oncology, vol. 23, no. 27, pp. 6771-6790, 2005.

[111] P. Johansson, S. Pavey, and N. Hayward, "Confirmation of a BRAF mutation-associated gene expression signature in melanoma," Pigment Cell Research, vol. 20, no. 3, pp. 216221, 2007.

[112] P. M. Pollock and P. S. Meltzer, "A genome-based strategy uncovers frequent BRAF mutations in melanoma," Cancer Cell, vol. 2, no. 1, pp. 5-7, 2002. 
[113] C. J. Marshall, "MAP kinase kinase kinase, MAP kinase kinase and MAP kinase," Current Opinion in Genetics \& Development, vol. 4, pp. 82-89, 1994.

[114] M. J. Garnett and R. Marais, "Guilty as charged: B-RAF is a human oncogene," Cancer Cell, vol. 6, no. 4, pp. 313-319, 2004.

[115] P. T. Wan, M. J. Garnett, S. M. Roe et al., "Mechanism of activation of the RAF-ERK signaling pathway by oncogenic mutations of B-RAF," Cell, vol. 116, no. 6, pp. 855-867, 2004.

[116] K. Hookim, M. H. Roh, J. Willman et al., "Application of immunocytochemistry and BRAF mutational analysis to direct smears of metastatic melanoma," Cancer Cytopathology. In press.

[117] J. P. Lott, "Vemurafenib in melanoma with BRAF V600E mutation," The New England Journal of Medicine, vol. 365, no. 15, pp. 1449-1450, 2011.

[118] M. S. Brose, P. Volpe, M. Feldman et al., "BRAF and RAS mutations in human lung cancer and melanoma," Cancer Research, vol. 62, no. 23, pp. 6997-7000, 2002.

[119] J. Dong, R. G. Phelps, R. Qiao et al., "BRAF oncogenic mutations correlate with progression rather than initiation of human melanoma," Cancer Research, vol. 63, no. 14, pp. 3883-3885, 2003.

[120] P. M. Pollock, U. L. Harper, K. S. Hansen et al., "High frequency of BRAF mutations in nevi," Nature Genetics, vol. 33, no. 1, pp. 19-20, 2003.

[121] W. Liu, J. W. Kelly, M. Trivett et al., "Distinct clinical and pathological features are associated with BRAF mutation in primary melanoma," Journal of Investigative Dermatology, vol. 127, no. 4, pp. 900-905, 2007.

[122] U. R. Rapp, M. D. Goldsborough, and G. E. Mark, "Structure and biological activity of v-raf, a unique oncogene transduced by a retrovirus," Proceedings of the National Academy of Sciences of the United States of America, vol. 80, no. 14 I, pp. 4218-4222, 1983.

[123] E. E. Patton, H. R. Widlund, J. L. Kutok et al., "BRAF mutations are sufficient to promote nevi formation and cooperate with p53 in the genesis of melanoma," Current Biology, vol. 15, no. 3, pp. 249-254, 2005.

[124] E. E. Patton, H. R. Widlund, J. L. Kutok et al., "BRAF mutations are sufficient to promote nevi formation and cooperate with p53 in the genesis of melanoma," Current Biology, vol. 15, no. 3, pp. 249-254, 2005.

[125] D. Dankort, D. P. Curley, R. A. Cartidge et al., "BRAF (V600E) cooperates with PTEN loss to induce metastatic melanoma," Nature Genetics, vol. 41, no. 5, pp. 544-552, 2009.

[126] Y. Chudnovsky, A. E. Adams, P. B. Robbins, Q. Lin, and P. A. Khavari, "Use of human tissue to assess the oncogenic activity of melanoma-associated mutations," Nature Genetics, vol. 37, no. 7, pp. 745-749, 2005.

[127] J. A. Curtin, J. Fridlyand, T. Kageshita et al., "Distinct sets of genetic alterations in melanoma," The New England Journal of Medicine, vol. 353, no. 20, pp. 2135-2147, 2005.

[128] A. Brozyna, B. Zbytek, J. Granese, J. A. Carlson, J. Ross, and A. Slominski, "Mechanism of UV-related carcinogenesis and its contribution to nevi/melanoma," Expert Review of Dermatology, vol. 2, no. 4, pp. 451-469, 2007.

[129] C. Bevona, W. Goggins, T. Quinn, J. Fullerton, H. Tsao, and R. Corona, "Cutaneous melanomas associated with nevi," Archives of Dermatology, vol. 139, no. 12, pp. 1620-1624, 2003.

[130] A. S. Yazdi, G. Palmedo, M. J. Flaig et al., "Mutations of the BRAF gene in benign and malignant melanocytic lesions,"
Journal of Investigative Dermatology, vol. 121, no. 5, pp. 11601162, 2003.

[131] B. Devitt, W. Liu, R. Salemi et al., "Clinical outcome and pathological features associated with NRAS mutation in cutaneous melanoma," Pigment Cell and Melanoma Research, vol. 24, no. 4, pp. 666-672, 2011.

[132] J. L. Maldonado, J. Fridlyand, H. Patel et al., "Determinants of BRAF mutations in primary melanomas," Journal of the National Cancer Institute, vol. 95, no. 24, pp. 1878-1890, 2003.

[133] R. Houben, J. C. Becker, A. Kappel et al., "Constitutive activation of the Ras-Raf signaling pathway in metastatic melanoma is associated with poor prognosis," Journal of Carcinogenesis, vol. 3, article 6, 2004.

[134] J. Lang and R. M. MacKie, "Prevalence of exon 15 BRAF mutations in primary melanoma of the superficial spreading, nodular, acral, and lentigo maligna subtypes," Journal of Investigative Dermatology, vol. 125, no. 3, pp. 575-579, 2005.

[135] Y. Cohen, E. Rosenbaum, S. Begum et al., "Exon 15 BRAF mutations are uncommon in melanomas arising in non sunexposed sites," Clinical Cancer Research, vol. 10, no. 10, pp. 3444-3447, 2004.

[136] M. T. Landi, J. Bauer, R. M. Pfeiffer et al., "MC1R germline variants confer risk for BRAF-mutant melanoma," Science, vol. 313, no. 5786, pp. 521-522, 2006.

[137] L. Pho, D. Grossman, and S. A. Leachman, "Melanoma genetics: a review of genetic factors and clinical phenotypes in familial melanoma," Current Opinion in Oncology, vol. 18, no. 2, pp. 173-179, 2006.

[138] N. Lin, K. Urabe, Y. Moroi et al., "Overexpression of phosphorylated-STAT3 and phosphorylated-ERK protein in dermatofibrosarcoma protuberans," European Journal of Dermatology, vol. 16, no. 3, pp. 262-265, 2006.

[139] F. J. Esteva, A. A. Sahin, T. L. Smith et al., "Prognostic significance of phosphorylated P38 mitogen-activated protein kinase and HER-2 expression in lymph node-positive breast carcinoma," Cancer, vol. 100, no. 3, pp. 499-506, 2004.

[140] E. Sprecher, R. Bergman, A. Meilick et al., "Apoptosis, Fas and Fas-ligand expression in melanocytic tumors," Journal of Cutaneous Pathology, vol. 26, no. 2, pp. 72-77, 1999.

[141] M. Hussein, A Haemel, and G. S. Wood, "Apoptosis and melanoma: molecular mechanisms," Journal of Pathology, vol. 199, no. 3, pp. 275-288, 2003.

[142] N. V. Fernandes, P. K. Guntipalli, and M. O. Huanbiao, " $\mathrm{D}$ - $\delta$-tocotrienol-mediated cell cycle arrest and apoptosis in human melanoma cells," Anticancer Research, vol. 30, no. 12, pp. 4937-4944, 2010.

[143] S. Medic, H. Rizos, and M. Ziman, "Differential PAX3 functions in normal skin melanocytes and melanoma cells," Biochemical and Biophysical Research Communications, vol. 411, no. 4, pp. 832-837, 2011.

[144] J. Downward, "PI 3-kinase, AKT and cell survival," Seminars in Cell and Developmental Biology, vol. 15, no. 2, pp. 177-182, 2004.

[145] J. M. Stahl, M. Cheung, A. Sharma, N. R. Trivedi, S. Shanmugam, and G. P. Robertson, "Loss of PTEN promotes tumor development in malignant melanoma," Cancer Research, vol. 63, no. 11, pp. 2881-2890, 2003.

[146] C. A. Torres-Cabala, W. L. Wang, J. Trent et al., "Correlation between KIT expression and KIT mutation in melanoma: a study of 173 cases with emphasis on the acral-lentiginous/ mucosal type," Modern Pathology, vol. 22, no. 11, pp. 14461456, 2009. 
[147] D. Handolias, R. Salemi, W. Murray et al., "Mutations in KIT occur at low frequency in melanomas arising from anatomical sites associated with chronic and intermittent sun exposure," Pigment Cell and Melanoma Research, vol. 23, no. 2, pp. 210-215, 2010.

[148] L. Cerroni, H. P. Soyer, and H. Kerl, "bcl-2 protein expression in cutaneous malignant melanoma and benign melanocytic nevi," American Journal of Dermatopathology, vol. 17, no. 1, pp. 7-11, 1995.

[149] H. Helmbach, P. Sinha, and D. Schadendorf, "Human melanoma: drug resistance," Cancer Research, vol. 161, pp. 93-110, 2003. 


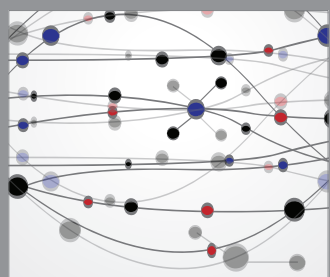

The Scientific World Journal
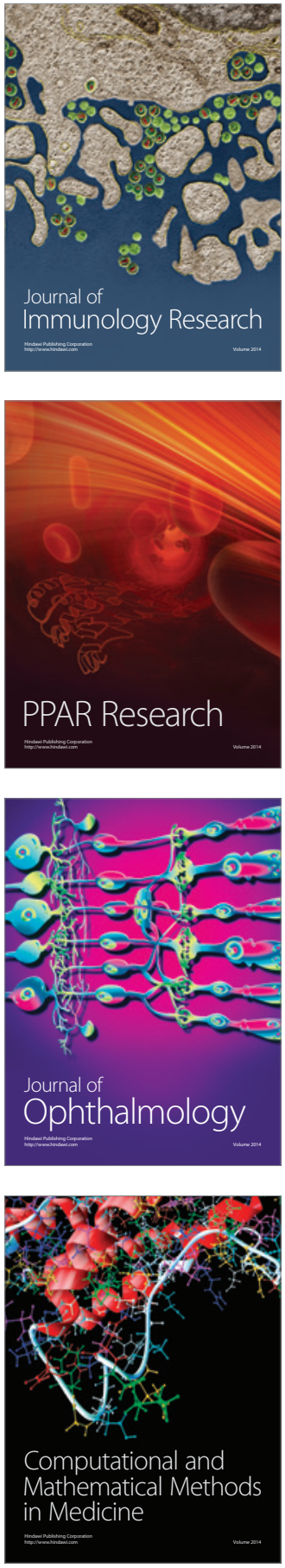

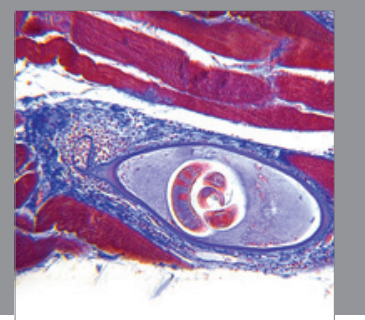

Gastroenterology

Research and Practice
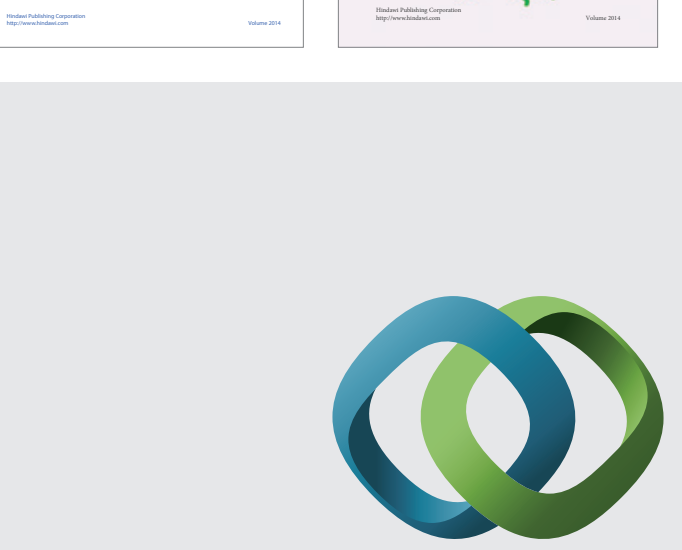

\section{Hindawi}

Submit your manuscripts at

http://www.hindawi.com
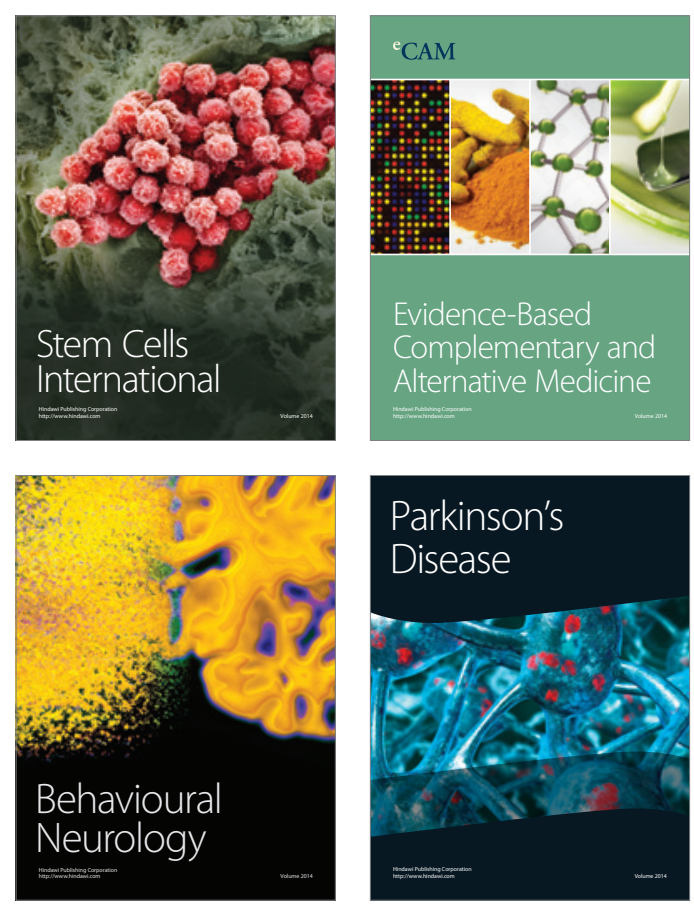

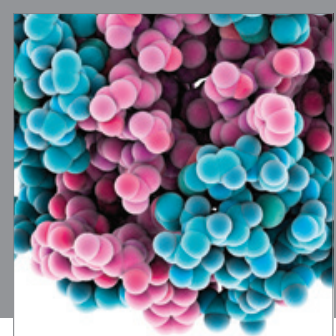

Journal of
Diabetes Research

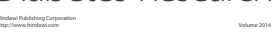

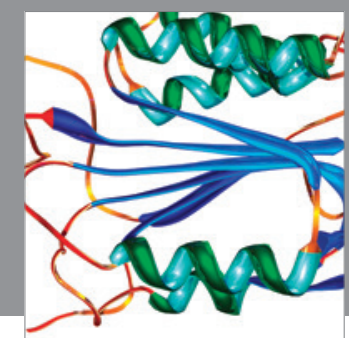

Disease Markers
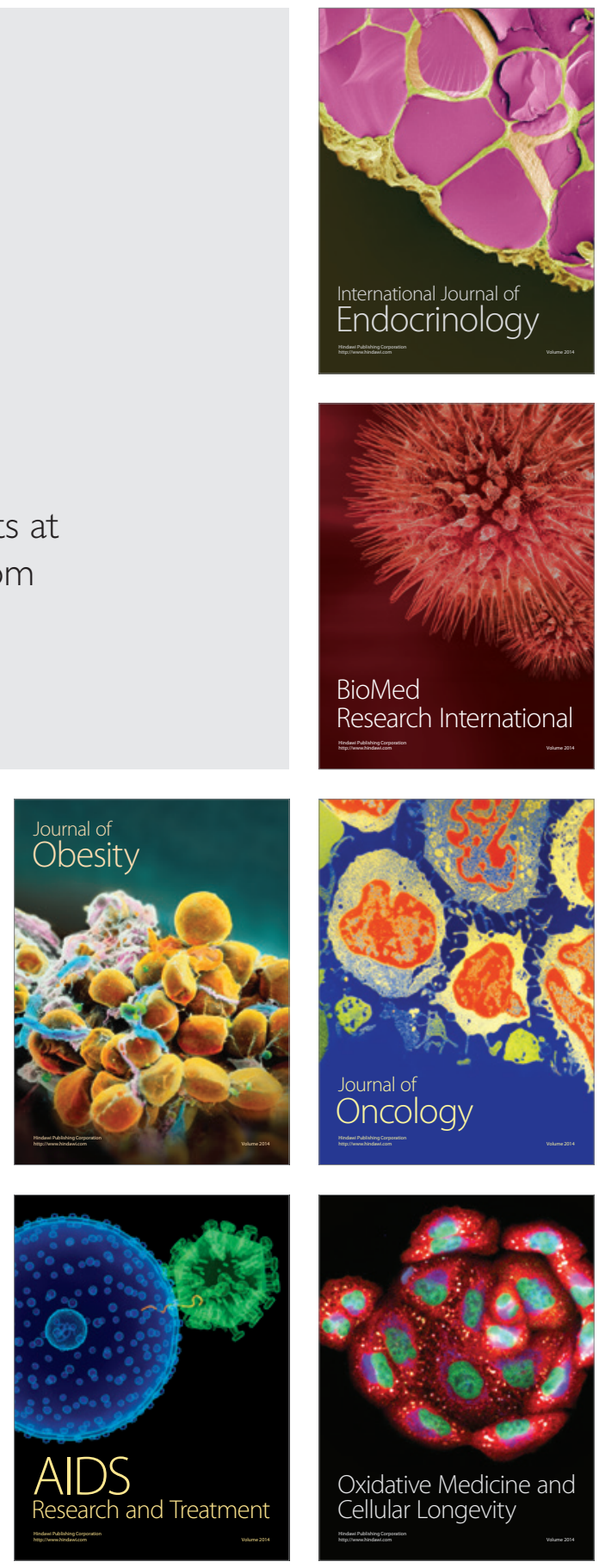